\title{
Interactive comment on "Terrestrial or marine? - Indications towards the origin of Ice Nucleating Particles during melt season in the European Arctic up to $83.7^{\circ} \mathrm{N}$ " by Markus Hartmann et al.
}

Markus Hartmann et al.

hartmannm@tropos.de

Received and published: 5 April 2021

Please see the attachments for our replies to the RCs.

Please also note the supplement to this comment:

https://acp.copernicus.org/preprints/acp-2020-1211/acp-2020-1211-AC1-

supplement.pdf

Interactive comment on Atmos. Chem. Phys. Discuss., https://doi.org/10.5194/acp-2020-1211, 2020. 